http://kitaibelia.unideb.hu/

ISSN 2064-4507 (Online) • ISSN 1219-9672 (Print)

(C) 2015, Department of Botany, University of Debrecen, Hungary

22 (1): 47-54.; 2017

DOI: $10.17542 /$ kit.22.47

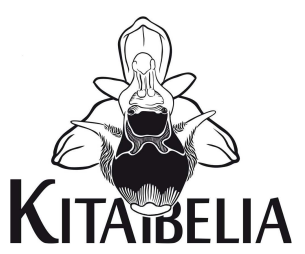

\title{
A herbáriumról (gondolatok és jótanácsok) ${ }^{1}$
}

\author{
FELFÖLDY Lajos $†$
}

„Mert nem igaz az, hogy az esméret gyönyörüségének tsak a' haszon volna a' rugója. Maga az esméret terjedése és szélesedése az ember okos lelkében a' legtisztább és nemesebb gyönyörüség érzésnek kútfeje."

DiósZEGi S. \& FAZEKAS M. (1807): Magyar füvész könyv. - Debreczen.

A növénygyűjtemény (herbárium) készítés - gyűjtés, preparálás, cédulázás - múzeumok, tudományos intézetek, esetleg iskolák és gyüjtőszenvedélytől fütött magánosok számára válhat céllá. Ez részint - a fenti mottó szellemében - a gyűjtemény-készítésért magáért történik. Másrészt azonban azért, mert a szentencia, hogy „növényismeret nélkül nincs botanika” ma is érvényes, és kétségtelen, hogy a növények megismerésének legbiztosabb és legegyszerűbb módja herbárium készítése és tanulmányozása. Emellett a terepen dolgozó botanikus bármilyen jó növényismerőnek is tartja magát - mindig találkozik olyan növényekkel, melyeket csak alapos vizsgálat után tud azonosítani, kénytelen is „gyüjteni” későbbi vizsgálat céljára.

Ha a gyűjtő valamilyen szempontból érdekes - a leírásnak nem teljesen megfelelő, vagy egy területre, esetleg az egész országra nézve új vagy kihaltnak nyilvánított - növényt talál, a bizonyító példányt érdemes (nézetem szerint szükséges) valamely nyilvános gyűjteményben (is) elhelyezni. Ha a kizárólag a növény pontos ismeretét célzó mintaszedést kicsit nagyobb gondossággal, „herbárium-példány”-ban gondolkodva végezzük, ha a préselésre kicsit nagyobb gondot fordítunk és a szárított növényt pontosan cédulázzuk és mindenki által hozzáférhető gyűjteményben helyezzük el, olyan értékes információtömeget hagyunk utódainkra, amilyet a nagy gyűjtő-elődök, Kitaibel Pál, BorBÁs Vince, SimonKAI Lajos, JÁVORKA Sándor, DEGEN Árpád, BOROS Ádám vagy KÁROLYI Árpád hagytak miránk.

Civilizációtól terhes, kapzsi korunkban gyorsan és vészesen fogynak növényeink eredeti termőhelyei, flóránk és faunánk, természetes növénytakarónk és annak állatvilága rohamosan pusztul, szegényedik. Ne szakítsuk meg lustasággal, nemtörődömséggel, oda nem figyeléssel azokat a herbáriumi lapokon rögzített pillanatképeket, melyek a folyamatot leírják és

${ }^{1}$ Felföldy Lajos nyugdíjas éveiben sok időt töltött a MTM Növénytára anyagának rendezésével. Ebben az időszakban (az 1990-es években) vetette papírra a herbáriumkészítéssel kapcsolatos tapasztalatait és a botanikusok mai generációja számára különösen tanulságos gondolatait. Bár az anyagot nem publikációnak, sokkal inkább vezérfonalnak, útmutatónak szánta, úgy véljük, hogy sokunknak hasznára válhat. A szerző szándékában állhatott a kézirat kiegészítése (például $A$ herbárium értéke a tudományos munkában és a Hogyan tovább? c. fejezetek egyes bekezdései esetében), ám az anyag e nélkül is kerek, így azt kiegészítések nélkül közöljük. Az itt megjelenő szöveg egyes gondolatai olvashatók a „125 éves a Magyar Természettudományi Múzeum Növénytára" című könyv (Magyar Természettudományi Múzeum Növénytára, Budapest, 1995; összeállította: Buczkó Krisztina) 7-8. oldalán, a "Néhány szó a herbáriumról" című fejezetben - a szerkesztők. 
melyek nélkül utódaink elképzelni sem tudják, miként lehet ezt a pusztulást nyomon követni, avagy áldozatos munkával gyógyítani (renaturálás). A növénygyűjtést tehát a kis-és nagyokosok, a jóra való restek és kényelmeskedők ál-természetvédelme és suttogó propagandája ellenére érdemes folytatni.

\section{A gyưjtés módszerei és etikája}

A herbárium-készítés módszertani lépései a következők: gyűjtés, preparálás (tartósítás), határozás, cédulázás és gyűjteménybe rendezés. Ha a kiszállás célja valamely gyưjtemény gyarapítása - múzeumi, iskolai bemutató vagy összehasonlító gyűjtemény - másképpen járunk el, mint ha csak terepmunkánk során a fajok pontos ismerete a cél.

Az első esetben minden „herbárium-érett” növényt összeszedünk, a közönségeseket is. A kezdeti próbálkozások után mindenki rájön, hogy mit takar a „herbárium-érett” fogalom. A sások, a keresztesvirágúak, ernyősök és a legtöbb fészkes virágzatú növény például csak terméses állapotban határozható meg. (Ha már ismerjük őket, vagy elég gazdag, jól határozott összehasonlító anyagunk van (természetesen herbáriumban!), az „éretlen” példányok is azonosíthatók.)

Fákról, cserjékről és hórihorgas dudvákról jellegzetes leveles-virágos-terméses ágat gyűjtünk, a kistermetű növényekből pedig annyi példányt szedünk, amennyi zsúfoltság nélkül elfér a herbárium lapon. A második világháború előtt még minden lágyszárú növényt kiástak és gyökerestől préseltek le. Ma már azonban természetvédelmi törvény védi ritkább növényeinket, de a jóérzés is tiltja természeti kincseink pusztítását, még gyűjtemény-készítés ürügyén is. Ha olyan növényt fedezünk föl, melyet nem ismerünk (tehát lehet szigorúan védett faj is!), akkor körülnézünk a környékén, hogy hány példány van belőle. Ha 5 vagy annál kevesebb tövet találunk, akkor próbáljuk a helyszínre vitt könyvvel meghatározni. Ha ez nem lehetséges, ne gyűjtsünk belőle mást, mint 1-2 virágot és néhány levelet, amit külön papírba burkolva vigyünk haza. A leszedett részeket gondosan szárítsuk (préseljük) és pontosan cédulázva, kapszulába téve herbáriumba is helyezhetjük. Ha 5-30 példányt találunk, egy szálat begyűjthetünk (néhány alsó levelét a tövön hagyva). Harmincnál több példányból anynyi szálat szedhetünk, amennyi szép „herbárium-példányt, azaz lapot” biztosít, de ritka (védett) növényt gyökerestől ne ássunk ki, még akkor se, ha a földbeli részek ismerete elengedhetetlen föltétele lehet az azonosításnak - ilyenkor a növényismerő kollégák és a nagy herbáriumok segíthetnek. (Természetvédelmi területen a gyűjtés engedélyhez kötött, a terület kezelője adhat ilyet!)

Különleges eset (még alig történt meg), ha halálra ítélt területen gyűjthetünk. Valamely környezet és/vagy természetvédelmi szervnek kellene lenni, amelyik lecsapolás, föltöltés, elárasztás, erdőirtás, fölszántás, beépítés, „melioráció” előtt botanikust küldene a területre, hogy annak minden növényét gyűjtse be. Ekkor természetesen minden fajból „teljes példányt" szedhetünk.

Az összeszedett növényeket haza kell vinni. A botanikus jelképe még a századfordulón is a gyüjtőszelence volt: egy hasáb- vagy henger alakú bádogedény, amit vállra akasztva vitt magával a gyűjtő, és amely légmentesen záródva megakadályozta a növények fonnyadását, kiszáradását. A hazavitelt egyszerűsíti az utóbbi idők nagy találmánya, a fóliából készült zsák, szatyor vagy zacskó, mert a növények megfelelően belehelyezve (herbáriumi lap méretűre hajtogatva) és összecsavarva, hűvös helyen akár egy hétig is frissen maradnak és később présbe tehetők. Eddigi gyakorlati tapasztalataink közül néhányat fölsorolunk:

- A növényeket hervadás vagy lankadás előtt helyezzük a fóliazsákba, lazán összehajtogatva (ha hosszabb, mint a zsák szélessége), majd a zsák szabad végébe göngyöljük őket. Ha megtelt (szabad vége olyan hosszú, mint a növényekkel teli része), hátzsákba vagy tarisz- 
nyába kerül és új zsákot kezdünk. Vigyázzunk, hogy a fóliazsákban lévő növényeket közvetlen napfény ne érje (például gépkocsi hátsó ablakában).

- Éjszakára, több napos gyüjtéskor akár 4-5 napra is, hűvös helyre kell tenni a csomagokat. Ilyenkor a napi zsákmányt, a különböző helyről származó teli zacskókat egy nagyobb fóliazsákba helyezzük, begöngyöljük, át is kötjük őket, és ha lehet, hűtőszekrényben tartjuk, ügyelve arra, hogy fagypont alá ne kerüljenek! Igen jól megfelel egy hűvös pince vagy árnyas, köves helyiség is.

- Vízi és szárazföldi növényeket ne gyüjtsünk ugyanabba a szatyorba, mert a szárazföldiek átnedvesednek és kiszárítva is „csapzottak” maradnak, megbarnulnak stb.

- Ha nagyobb területet járunk be, legokosabb a különböző helyről származó anyagot másmás zsákba helyezni, amelybe puha grafit ceruzával írt cédulát helyezünk, amit esetleges átázás után is el lehet olvasni. Jól bevált az is, hogy az egy helyről származó növényeket papírba burkoljuk, jelzéssel látjuk el és a fóliazsákba, szatyorba több papírcsomagot helyezünk.

- Vannak kényes virágú növények (például a rence, boglárkák), melyeknek virága lehullik, tönkremegy a fóliazsákban és elkeveredik a többi növény között. Ezeknél néhány virágos példányt papírba csavarva a szatyorba helyezünk, pár virágzatot irkalap nagyságú keménypapírlap közé fogott újság- vagy szűrőpapír „herbáriumba” gyüjtünk. (A növényt és a virágzatot ugyanolyan jellel kell ellátni). Kistermetű, sűrű párnában növő fajból késsel talajjal együtt tenyérnyi darabokat vágunk, földes felükkel egymásra helyezzük őket és így burkoljuk papírba, hasonlóan a talajlakó mohok mintáihoz. Otthon aztán a földet kimossuk és így nemcsak „természetes fekvésű”, de jól tanulmányozható és csinos mintát nyerünk, ami kapszulában kerül a gyüjteménybe.

\section{Preparálás (tartósítás)}

A gyűjtőút végeztével a fóliazsákban, szatyorban hazaszállított növényeket minél hamarabb mappába, „présbe” kellett tenni. A mappa valamikor két erős keménypapír lap közé rétegezett újságpapír volt, amelyben a növényeket szétterítve elhelyezve és hevederrel összeszorítva préseltük le. A növényekkel teli mappa cipelése, különösen több napos gyüjtőutakon komoly erőfeszítést kívánt. A herbárium-készítés során a növény a legősibb tartósítási módot, a szárítást („aszalást”) az összegyưrődést, zsugorodást megakadályozó enyhe vagy erősebb nyomással kombinálva „szenvedi el” a présben, amit követően azután évszázadokig őrizhető, bármikor elővehető, újra és újra tanulmányozható.

Mivel Magyarországon a tartósításra legalább másfélszáz éve használt vékony szürke és fehér itatós nehezen hozzáférhető a kereskedelemben, a szárítást jobb híján újságpapír között végezzük. Ebben az esetben a papírt eleinte naponta cserélni kell, de mivel a félig száradt növényeket nem rakosgathatjuk át meg át, kétféle papírt különböztetünk meg. Egyrészt a legalább 25 lapból álló „szárítópapír” csomókat, amiket iratkapoccsal, puha pamuttal vagy vékony zsineggel összefüzünk (régen szürke itatósból álltak), másrészt az „itatós íveket”, amelyekbe a növényt helyeztük (ez régen fehér itatósból készült). Ez utóbbiaknak célszerű elütniük a szárítópapírtól, hogy cserélés közben nehogy a szárítópapír közé keveredjenek. (Én eleinte erre a célra is újságpapírt használtam, amire vízálló festékkel (nemeztoll) nagy Xeket rajzoltam. A mai újságok között vannak sárga vagy zöld színú papírra nyomottak is, ami jó megoldást kínál. Később fehér, nem kreppelt szűrőpapírból szabtam 295×445 mm-es íveket. Kreppelt szűrőpapír nem használható, mert a nagy, sima felületủ levelekre nyomtatja a papír cifráját.)

Amint arra már a gyűjtőzsákba helyezés kapcsán utaltunk, mindjárt a munka elején döntenünk kell a formátum kérdésében, de legkésőbb a présbe helyezéskor. Célszerú újságpapír méretben gondolkodnunk. A présbe csak egyforma szárítópapír-lapok kerülhetnek, ezeknek 
nagysága határozza meg az itatós ívét, sőt a préselhető növény nagyságát is. (Jó arra is gondolni, hogy nagyobb papírból kisebb szabható, de fordítva nem.) A jelenlegi hazai újságok közül a „közepes méretűek” nagysága javasolható: 320×480 mm. Ezeknek ugyanis harmonizálni kell a herbárium-lap méretével is, amiről később szólunk, de már ebben a munkafázisban figyelembe kell venni.)

Végül egy figyelmeztetés: egy-egy kirándulásról csak annyi növényt hozhatunk haza, ami szárítópapír-vagyonunk felében elfér, hiszen a másik fele a cseréhez kell!

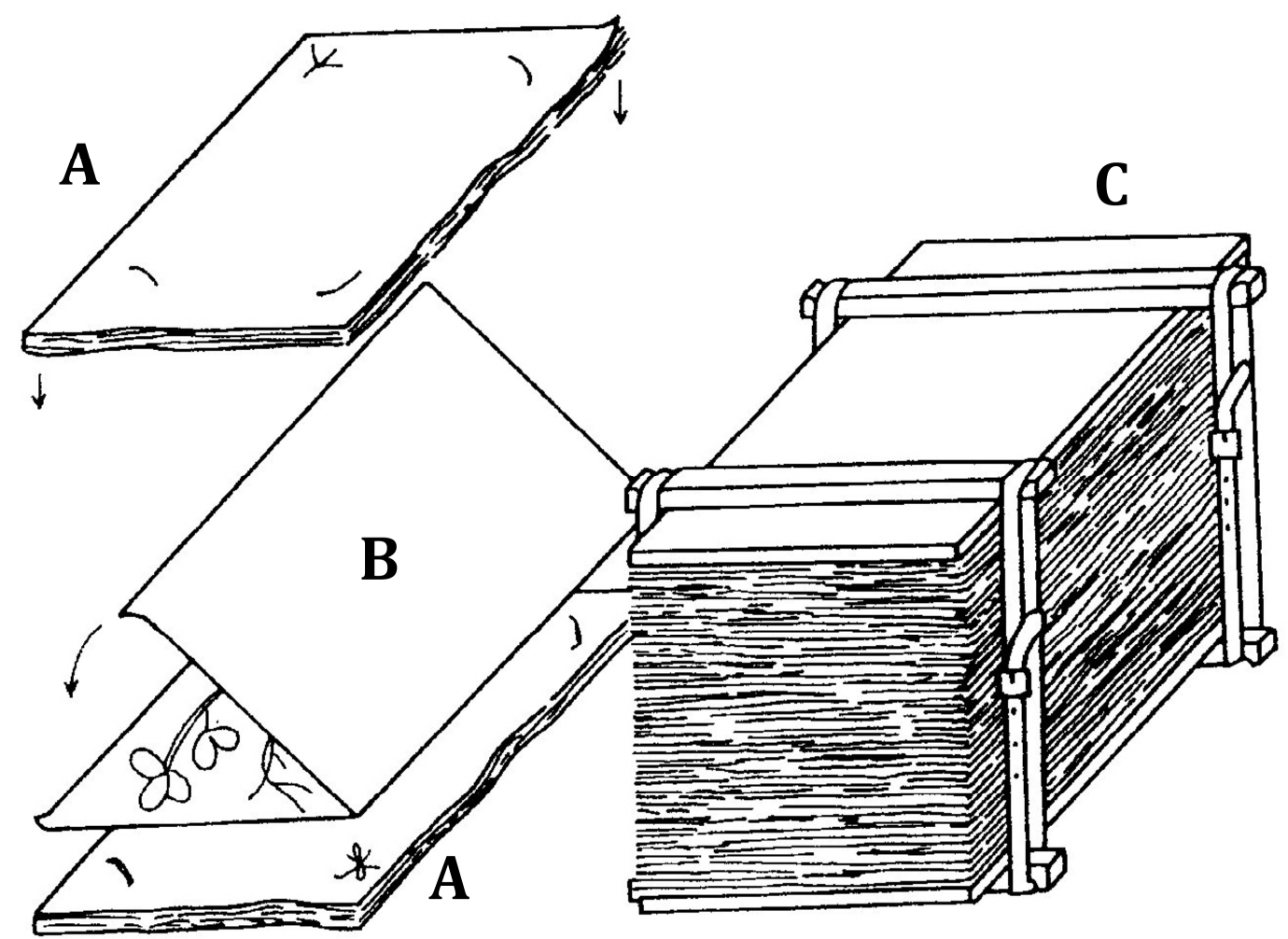

1. ábra. Herbárium-készítés.

A = szárítópapír-csomók, B = itatós ív a növénnyel, $\mathrm{C}$ = hevederrel összefogott deszka-prés

A preparálás menete („présbe rakás”) a következő: Az asztalra helyezett szárítópapírcsomóra nyitva itatós ívet terítünk. A fóliazsákból kiemelt, lerázogatott, megtisztított növényt az itatós ívre helyezzük. Ha hosszú, összehajtogatjuk, leveleit kisimítjuk, ágait, virágait csinosan elrendezzük, kis cédulát helyezünk mellé a lelőhely megjelölésével és az ívet ráhajtjuk. Erre szárítópapír-csomó jön, amire a következő itatós ív, benne növénnyel és így tovább. Ha a préselendő példány dús lombú, illetve virágzatú, akkor hajtások (levélcsomók), illetve virágzati ágak közé kisebb újságpapírdarabokat helyezünk, hogy a barnulást (enyhe rothadást) megakadályozzuk.

A préselést csavarorsós fapréssel (aminek muzeális értékű példányai a Növénytárban láthatók) vagy ennek híján hevederrel, kötéllel összekötött, illetve nagy súllyal lenyomott préssel végezzük (1. ábra). A legegyszerűbb mód, ha 2-3 téglát tisztára mosunk, megszárítjuk, majd vastag csomagolópapírba burkoljuk. A papírba rétegezett növényekre megfelelő szilárdságú deszka jön, amit a téglákkal lenyomatunk. (Meg kell azonban jegyezni, hogy szép preparátumot csak erőteljes préseléssel kapunk. Ennek nem csak az az előnye, hogy az ala- 
posan ellapított növények kisebb helyet foglalnak el a herbáriumban, hanem lényeges momentum, hogy a vastag szárú fajok levelei gyűröttek, ráncosak maradnak, ha nem kapnak kellően nagy nyomtatást, mivel a szár „megvédi” őket a szükséges lapítástól.)

Másnap száraz szárítópapír-csomót helyezünk az asztalra, a présről levesszük a téglákat vagy lecsatoljuk a hevedert, leemeljük a deszkát és a legfölső szárítópapír-csomót, az itatós ívben lévő növényt a száraz papírra fektetjük. Ekkor óvatosan fölemeljük az itatóst és ellenőrizzük növényünk elhelyezkedését, amit ilyenkor még elég könnyű javítani: a leveleket kisimítani, összeakadt, rendetlen ágakat rendbe tenni stb. (a szárítás későbbi idejében ez már nem lehetséges). A letakart itatósra újabb száraz szárítópapír-csomó jön és ilyen módon az egész prést „átrakjuk”. A nedves szárítópapírt kiteregetjük száradni. A mai szűkös lakásviszonyok között ez a herbárium-készítés legkényelmetlenebb mozzanata. Az állandó helyhiánnyal küzdő intézetekben sem egyszerű feladat, de nélküle eredményes munka nem várható (padlás?).

Az átrakást 3-4 napig naponta, azután kétnaponta végezzük, míg a növények teljesen ki nem száradnak: fölemelve nem konyul le a végük, tapintásuk nem „hideg” stb. A présből kivett növényeket a feldolgozásig legokosabb újságpapír ívekben tartani.

\section{Növényhatározás - cédulázás}

A növényhatározáshoz a határozókönyvön kívül szükséges, hogy pontosan ismerjük a növények testrészeit, amit a legtöbb határozókönyv „Az alaktani kifejezések magyarázata” címmel részletesen tárgyal. A növények tanulmányozásához erősebb (8-12×-es) kézinagyító és mm beosztású mérce (célszerűen mm-papír szelet) szükséges. Ritkábban erősebb nagyítású preparáló mikroszkóp használata is célszerű, sőt, nem egyszer mikroszkópiai preparátum készítésétől sem tekinthetünk el. Ehhez a herbárium-példány kis részét (virágát, termését, levelét, szár-részletét) leválasztjuk és kémcsőben vagy kis főzőpohárban vízben „első forrásig” melegítjük, majd kihűlés után a szirmot, vékony levelet egy csepp vízben tárgylemezre terítjük, a szárból vagy levélből két bodza- vagy napraforgó-bél illetve „hungarocell” darabka közé fogva borotvával vagy zsilett pengével metszetet készítünk és vízben fedőlemezzel lefödve vizsgáljuk (100×-os nagyításnál több ritkán szükséges). (A határozás biztonságát növeli a jól határozott herbáriumi összehasonlító anyag, vagy jó növényismerő szakember revíziója.)

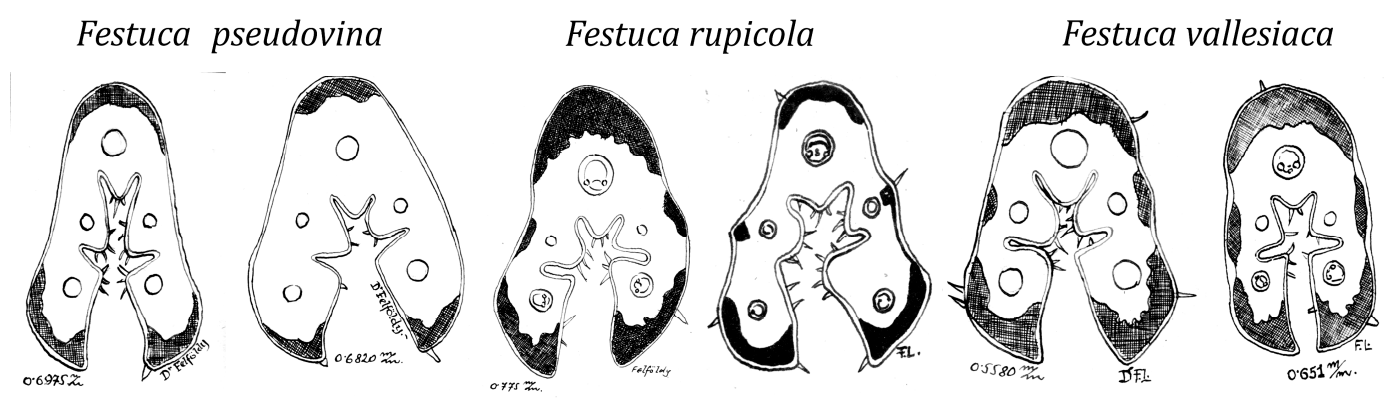

2. ábra. Herbáriumi Festuca példányok levél-keresztmetszetei

A préselt növény (függetlenül attól, hogy meg van-e határozva vagy nincs) csak hiteles cédulával válik „herbárium-példány”-nyá és egyúttal florisztikai-növényföldrajzi adattá. Ma, amikor a növények elterjedése, jelenlétük vagy hiányuk, megjelenésük vagy eltűnésük a környezetminősítés döntő tényezői, különösen fontos a pontos, térképre vihető cédulázás. Még a XX. század harmincas éveiben is elégnek látszott például a „Balaton” vagy „Velencei-tó” megjelölés, ám az újabb kutatások fölfedték a tavon belüli „vízminőségi táj” fogalmát és jelentőségét, aminek céduláinkon is jelentkeznie kell. 
A florisztikai (és faunisztikai) adat négy nélkülözhetetlen részből áll:

$$
\begin{aligned}
& \text { - a növény tudományos neve } \\
& \text { - a gyűjtés időpontja (év, hó, nap) } \\
& \text { - pontosan azonosítható gyűjtőhely } \\
& \text { - a gyưjtő neve }
\end{aligned}
$$

Ezek közül csupán a gyűjtőhely megjelölése lehet többféle, azaz kérdéses: a herbáriumi cédulán részint közigazgatási, részint földrajzi (topográfiai?) helymegjelölések szerepeltetendők, így a megye, a helység és a határrész, dűlő, illetve a hegy, völgy, rét, erdő, vízfolyás, tó, mocsár stb. neve. Ha az utóbbit térképről olvassuk le, egyszerűen idézőjelbe tesszük, ha nem hivatalos, közismert, vagy „bennszülöttektől” nyert névről van szó „nevezett” jelzőt használunk. Amikor csak lehetséges, a gyűjtőhelyet ennél is pontosabban azonosítani kell, megjelölve a térképi koordinátákat, (természetesen a térkép adataival, jelzeteivel együtt, mivel a térképek vetületi rendszere /koronként is/ változó). Célszerű lehet a térképezési hálózatok (UTM-, stb.) kódját is megadni. Szokás még a cédulára vezetni a tengerszint fölötti magasságot is (főleg hegyvidéken szükséges!). Ugyancsak érdemes a kőzet-, illetve ha lehet, a talajminőséget, valamint a növényzetet (társulást) megnevezni. Minél több hiteles és megbízható információ van a cédulán, annál értékesebb.

A cédula nyelve századunk közepéig mondhatni kizárólag latin volt, ma terjed az angol nyelvü, de elfogadható a pontos magyarnyelvű cédulázás is.

\section{A gyűjteménybe rendezés lehetőségei}

A kezelhetőség, kímélet és csinosság kedvéért a szárított, meghatározott és cédulázott növényeket enyvezett papírcsíkokkal herbárium-lapra ragasztják. (Az öntapadós ragasztószalag, „Tixo” és egyebek nem váltak be!)

A herbárium lap anyaga célszerúen nem túl kemény karton, de bármilyen vastagabb papír (rajzlap jellegű) megteszi, amivel szemben az a követelmény, hogy két alsó sarkánál fogva „tartása legyen”, ne hajoljon vissza. A lap mérete ízlésünktől, pénztárcánktól, a rendelkezésre álló szekrény mélységétől stb. függ. A debreceni és a budapesti (füvészkerti) egyetemek herbáriumának mérete $425 \times 255( \pm 5) \mathrm{mm}$. Az ennél kisebb lap a nagy termetű növények fölragasztásánál gondot okoz. A Magyar Természettudományi Múzeum Növénytárának jelenlegi lapmérete: $460 \times 320 \mathrm{~mm}$.

Nem hallgathatjuk el, hogy a fölragasztás kiadást és sok munkát kíván, a nagyon eltérő (sokkal kisebb) méretű lapok miatt a más (például a természettudományi múzeumi, növénytári) herbáriumba soroláskor a növényt le kell szedni a lapról és átragasztani, ami vesződséges, a példány könnyen megsérül, a lap jobb alsó sarkába ragasztott cédula rendszerint tönkremegy, ezért helyeselhető, ha a gyüjtő egyszerű papírívekben (célszerűen egyforma újságpapírban) tartja gyüjteményét.

A herbárium-rendezésnél egyetlen döntő szempont van: bármelyik növénypéldányt hoszszabb keresgélés nélkül meg kell találnunk. A munka kezdetén (amíg legföljebb pár száz lapról van szó) a legjobb fajok szerinti $\mathrm{ABC}$ sorrendben tartani a lapokat. Az általánosan elterjedt nézettel szemben a gyüjteményben ugyanabból a fajból több, más helyről vagy más időpontból származó példány van. A fajon belül a sorrend például a vármegyék alfabétikus sora is lehet.

A herbáriumnak a gondatlan kezelésen kívül (töredezés, cédulacsere) csak egyféle ellensége van, éspedig a rovarkártevők ${ }^{2}$. Ezek nagy részének petéje vagy lárvája már gyűjtéskor a növényben van, átvészelve a préselést, kikelnek és néha fölismerhetetlenségig összerágják a szárított növényt. Kisebb részük a kész gyűjteményt fertőzi. Ez ellen a klasszikus botanika szénkénegezéssel védekezett: a faszcikulusokat bizonyos időközökben, légmentesen záró térben, vízzárral „tömített” szénkénegező ládában, a mérgező, tűz- és robbanásveszélyes

2 Párás, hűvös helyen penészesedhetnek a lapok, illetve a mérgezéshez használt vegyszerek is okozhatnak károkat. - a lektor megjegyzése. 
szénkéneg (szén-diszulfid, $\mathrm{CS}_{2}$ ) gőzének tette ki 3-5 napra és újabb anyagot csak szénkénegezés után osztott a gyưjteménybe. Légmentesen záró szekrényekben a mérgezés a gyüjtemény kivétele nélkül végezhető. Ilyesmit magánember csak igen kedvező (anyagi) körülmények között engedhet meg magának.

(A modern szintétikus inszekticidek ilyen irányú használatának lehetőségét kísérletekkel kellene eldönteni, például hat-e a fóliazsákban légmentesen bekötött faszcikulus kártevőire valamely kereskedésben kapható, légtérben ható irtószer például Chemotox? Én szénkénegezés helyett szárítás után, az itatóspapír ívben lévő növényeket szabadban vagy nyitott ablak mellett Chemotox vagy a kevésbé büdös és a felületen tovább maradó Molytox rovarirtóval permetezem be mintegy tíz éve és soha sem tapasztaltam férgesedést. Megjegyzendő, hogy a nagy herbáriumok némelyikében, például az MTM Növénytárában a szénkénegezést a hidrogénfluroiddal /HF/ történő mérgezés váltotta föl ${ }^{3}$; ennek feltételei ugyanolyanok, mint a szénkénegezés esetében, jól záródó szekrényajtók, egy hétig tartó zárlat).

\section{A herbárium értéke a tudományos munkában}

Elérkeztünk az írás legfontosabb üzenetéhez: a herbárium értéke a tudományos munkában szinte felbecsülhetetlen. A tervszerủen rendezett, jól gondozott növénygyüjtemény fölhasználási területe igen sokrétú. Eddigi tapasztalataink szerint (némiképp redundáns) pontokba szedve:

- valamely terület flórájának vagy ritka növényeinek bizonyító anyaga,

- az újonnan leírt taxonok típuspéldányai,

- az állandóan változó szemléletű rendszertani kutatás alapja,

- ismeretlen növények meghatározásának ellenőrzése (összehasonlító herbárium),

- alaktani, anatómiai, szövettani vizsgálatok tárgya és bizonyos jellegü növénykémiai elemzések anyaga,

- a kísérlet taxonómiai vagy fenológiai vizsgálatok herbáriumban rögzíthető anyagának biztosítása,

- hazánk természeti környezetére vonatkozó mintegy másfélszáz évre visszamenőleg érvényes, növényekben megőrizhető információk fönntartása,

- a jelenleg folyó környezetromlás (-rombolás) dokumentálása tudatos gyűjtésekkel,

- a környezetminősítés herbáriumban őrizhető bizonyítékainak tárolása,

- a növénytan tudománytörténeti adatainak tárháza,

- az általános művelődéstörténet számára a gyüjtés időszakának technikai, technológiai, ízlésbeli, esztétikai stb. szemléletének tettenérése,

- botanikus elődök és a hazai növénykutatás herbáriumban föllelhető relikviáinak őrzése,

- oktatás, kiállítások, illusztráció, demonstráció.

Ehhez a fölsoroláshoz nem kell sok magyarázat. Kitúnik belőle, hogy a növénygyüjtemény nemcsak a terepkutató botanikust tanítja növényismeretre, rendszertanra és szolgáltat számára adatokat a növények elterjedéséről és fajon belüli változatosságáról, de hasznosan tanulmányozhatja lapjait a muzeológus, a botanika- és művelődéstörténettel foglalkozó történész, a természet-, sőt környezetvédelemmel foglalkozó kutató, a természet és az ember viszonya iránt érdeklődő minden művelt ember.

Ám hogy mégis alátámasszuk az elmondottakat, - a teljesség igénye nélkül - elősorolunk néhány érzékletes példát. A korábban „Himantoglossum hircinum”-nak tartott, igen ritka, (fokozottan védett) növény hazai populációit vizsgálva csupán az utóbbi években derült ki,

${ }^{3}$ A Növénytárban ma már nem hidrogénfluoriddal történik a mérgezés. - a lektor megjegyzése. 
hogy azokat valójában két másik faj, a H. caprinum (M. Bieb.) Spreng. ${ }^{4}$ és a $H$. adriaticum $\mathrm{H}$. Baumann példányai alkotják - ezek elterjedését, korábbi feltalálási helyeiket a herbáriumi példányok rajzolják ki.

\section{Hogyan tovább?}

A nagy magánherbáriumok kora lejárt. Pedig ezek a herbáriumok számos kiváló szakembert neveltek! Egészen más műveltségű és foglalkozású emberek (leggyakrabban orvosok, gyógyszerészek és egyházi személyek), megigézve a növényvilág változatos szépségétől, előbb csak gyưjtőszenvedélyük kielégítésére gyűjtöttek növényeket, majd megtanulva a herbáriumkészítés és növényhatározás mesterségbeli módszereit, kiváló amatőr kutatókká váltak.

A mai élet anyagi szűkössége és az emberiség mentális torzulása („legföljebb pénzt érdemes gyüjteni") nem kedveznek az ilyenféle úri passzióknak. A folyamatosság fönntartása tehát a még élő közületi herbáriumokra marad.

Jó lenne számbavenni a ma Magyarországon „élő” herbáriumokat: azokat, melyeket ma is gondoznak és fejlesztenek, ahova bárki, a gyűjtött növényeit elhelyezheti, sőt, melyek örülnek ennek vagy - horribile dictu! - fizetnek érte.

Azoknak, akik saját herbáriumot nem készítenek, de akár a pontos meghatározásért, akár új adataik igazolására növényt visznek haza, nem árt néhány tanácsot megfogadni, hogy öszszeszedegetett növényeik valamely herbárium polgáraivá válhassanak és utódaik információkészletét növeljék:

- Gyűjtéskor, a védett vagy ritka növények maximális kíméletét szem előtt tartva igyekezzenek „herbárium-példány” méretben gyűjteni: fából, cserjéből, nagy termetű kórókról közepes újságpapíron elférő mintát vegyenek, kisebb növényekből annyi példányt, amennyi ugyanilyen nagy lapon zsúfoltság nélkül elfér.

- A növényeket újságpapír között préseljék le. A préseletlen, csomós, összekuncsorodott példány nem alkalmas tanulmányozásra és lehetetlenné teszi a faszcikulusba kötést.

- A préselt növényt egész újságpapír ívben tartsák, ne ragasszák föl (hacsak az elhelyező herbáriumtól nem kaptak az abban használt formátumú herbáriumlapot).

- Olvasható kézírással, írógéppel vagy szövegszerkesztővel írt cédulán szerepeljen a gyűjtőhely megyéje, az a helység melynek közigazgatási területén van, a lelőhely közelebbi megjelölése (erdő, völgy, tó, patak stb. neve), a gyűjtés napra pontos dátuma, a gyűjtő (esetleg határozó vagy revideáló) neve, és minden megjegyzés, ami a növénnyel kapcsolatban érdemes.

Mondanivalónkat FEKETE Gábor5 két gondolatával zárjuk: „Devalvációktól terhes korunk pozitív anakronizmusa, hogy a nagy közgyüjtemények, közöttük a nagy herbáriumok értéke egyre nő, szerepük felértékelődik. Modern taxonómia és szisztematika herbáriumok nélkül változatlanul elképzelhetetlen.” és „... az utóbbi évtizedekben drámai, a szokásost messze meghaladó gyüjteménykoncentráció zajlott le. Amint a patakok rendre a nagy folyóba igyekeznek, úgy olvadtak be sorra a Növénytár tároló szekrényeibe a nagy magángyüjtemények, sőt közgyüjtemények anyagai. Ez a kialakult monopolhelyzet már-már veszedelmes."

Sapienti sat, a hülye még kérdezősködik.

\footnotetext{
${ }^{4}$ A nálunk korábban $H$. caprinum-ként számon tartott növényről (ugyancsak herbáriumi példányok vizsgálata révén) azóta bebizonyosodott, hogy korábban le nem írt faj: H. jankae Somlyay et al. - a szerkesztők.

${ }^{5}$ FeKete G. (1995): Előszó. - In: Buczkó K. (szerk.), 125 éves a Magyar Természettudományi Múzeum Növénytára. Magyar Természettudományi Múzeum Növénytára, Budapest, pp. 5-6.
} 